\title{
GSA Tomorrow: An Open Challenge to Promote the Future of Geoscience
}

\author{
Kristin M. Dorfler, Macromolecules Innovation Institute, Virginia Tech, Blacksburg, Virginia 24061, USA, kmdorf@vt.edu; \\ Anke M. Friedrich, Ludwig-Maximilians-University Munich, Department of Earth and Environmental Sciences, \\ Luisenstr. 37, Munich, Bavaria 80333, Germany, friedrich@lmu.de
}

\section{INTRODUCTION}

The future of geoscience rests on your shoulders. Geologists are passionate about their science and discuss their interests with vigor, firmly understanding why geoscience is as important to society as physiology, agriculture, or engineering. In many cases, non-geologists don't see the clear importance and implication of the profession, outside of natural disasters and events that have immediate and apparent human effects. Countless geo-scientists ${ }^{1}$, including professionals, academics, and students, are already vocal self-advocates; however, in our currently digital world, where information can be instantly disseminated at the push of a button, it is time we took a collective effort as the Geological Society of America to actively emphasize the importance of science to the non-geologist, forming a movement to assertively advocate for our field. We invite you to contribute to this discussion by responding with succinct, measurable, and clear reasons on how what you do affects society. Our collective views could be used to guide non-geologists to advocate for geoscience just as non-physicians advocate for medical advances. GSA is as effective as its members, who make up 21Scientific Divisions, which have numerous, tangible impacts on society. As GSA continues focusing efforts on the advancement of the Society into the twenty-first century, we are taking a critical look at what the Society is doing, whom it is doing it for, and how it could be doing it better.

\section{PROGRESS IS A GOOD THING}

The world has changed since GSA was founded in 1888. Integrated circuits have allowed us to use personal computers, we use antibiotics to fight deadly infections, wireless communication provides global access, and we can instantly transmit high-resolution videos to our friends. Technology advances because of society and society advances because of technology. Yet, technological advancement would not be possible without the discovery, understanding, and properties of raw materials, a direct outcome of the unending commitment of the geoscience community. We are all driven by an insatiable human desire for a better understanding of our world and everything it containsnot strictly speaking of geoscience, but all science, technology, engineering, and mathematics fields, and the humanities. What we learn now is different than what we learned in 1888 . What university students learn in their geology courses today is different than what the authors of this contribution learned, and what the authors of this contribution learned is quite different from each other. This is the nature of progress. This is a good thing.

The tools we use to study geoscience are adapting, innovating, and modernizing the way we carry out our observations, research, and achievements. Instead of carrying a compass, paper topographic map, and notebook, students today have the option to download applications on a single smartphone to carry out the same functions. Many research groups use drone technology to assist with mapping rather than risking their safety on dangerous cliffs or simply inferring an inaccessible terrane. The results from science conducted with modern tools can be just as accurate, if not more so, than work conducted with conventional technology. It's analogous to the way art has changed over tens of thousands of years - the tools have changed from carbon ash and hands, to mineral-based dyes and horse-hair brushes, pencils and ink pens, to computer software. The end product (from a petroglyph to a Monet) is still considered art but comparing pictographs to $3 \mathrm{D}$ graphics is like comparing William Smith's 1815 geologic map of Britain with the British Geological Survey's iGeology app, which provides multiple layers of geologic information, photos, and text about the country's geology at the touch of a screen. If our profession will continue to evolve based on discovery and innovation (both internal and external to geoscience), how do we visualize geoscience in the next 50 years? The next 100 years?

\section{THE GEOSCIENCE DISCIPLINE}

It's important to briefly reflect on how geoscience developed into what it is today. Ask a geoscientist "Who was the first geologist?" and the same few names are likely mentioned: Werner, Hutton and Smith, or Steno. Yet, Werner's paid profession was as a mining and mineralogy instructor, Hutton was a retired physician and farmer when he began to explore geology, Smith was a canal worker, and Steno was a professor of anatomy. Early "renaissance men" including Aristotle,

GSA Today, https://doi.org/10.1130/GSATG377GW.1. Copyright 2018, The Geological Society of America. CC-BY-NC.

${ }^{1}$ Geoscience/geoscientists is defined as all subdisciplines that are recognized as Scientific Divisions of GSA (geoarchaeology, karst, planetary geology, etc.), and may be extrapolated to areas that cross over to other subdisciplines that may not be strictly recognized as a GSA Scientific Division. 
Pliny the Elder, Al-Biruni, and Shen Kuo ruminated about the origin of Earth, geomorphology, minerals, and geologic time, yet they weren't considered geoscientists. Mineralogy had been a well-regarded profession for decades, as had mining, metallurgy, cosmogony, and natural history (Woodward, 1911; Gohau, 1991). The first paid geologist was possibly B. Faujas de Saint-Fond, who, in 1793, was appointed to a geologist teaching position at the National Museum of Natural History in France (Gohau, 1991). The discipline of geoscience today coalesced from many fields and developed based on human needs through maturity of thought and understanding of the world around usit changed as we advanced. Just as scientists take multiple "trains of thought" to come to a well-thought-out, logical conclusion, it has taken multiple lines of study to produce the (expansive) geoscience profession today. Would Smith be upset at the thought of our students mapping with ArcGIS software? Would Henry Sorby banish desktop scanning electron microscopes in his laboratory? Just as important, would Adam Smith be alarmed at how geological information and events (like the Eyjafjallajökull eruption) significantly impact our economy (Häggquist and Söderholm, 2015)? Other disciplines can be as reliant on geoscience as we are on them-everything is interdisciplinary to an extent. Yet, as we continue to catapult into a society based on manufacturing and development using novel, human-made materials, we are at the perfect opportunity to articulate the value of our earth-based profession.

\section{THOUGHT EXPERIMENT}

As a thought experiment, consider the question: what would happen if all geoscientists stopped practicing their science? Would the average person's life change? own their tools today, would the energy industry suffer? New resources for the rare earth minerals that power our smartphones may not be discovered if exploration geochemists walked away.
If hydrologists took a permanent vacation, would we still have clean drinking water? It could be argued that the outcomes of a study on mantle physics have as much of a personal significance as a study on natural hazards. Through geophysical research, we have detected that there is a lot more water in the earth than on it and that the water cycle, which is vital to life, may be closely tied to geologic processes (Pearson et al., 2014; Fei et al., 2017). Geochemical research on lead isotopes in the 1960s led to the awareness and understanding of lead contamination and poisoning, which are problems still facing society. From sedimentology, to petrology, to tectonics, to geophysics, if a geoscience field ceased to exist, how might human advancement be changed in ways that even the least geo-enthusiast could appreciate?

As a second thought experiment, consider how life might be altered if notable geologists never existed. For instance, what if F.W. Shotton never used hydrogeology to aid in development of potable water supplies for British forces in the Middle East and northern Africa during World War II (Rose and Clatworthy, 2008)? Through careful geological analysis and test drilling, Shotton derived safe drinking water from carbonate sediments, keeping the 8th Army hydrated and healthy to go on to defeat Nazi field marshal Erwin Rommel's army at El Alamein. If history was altered, how might our world look different today? If our modern geoscientist leaders step away, how might our world look different tomorrow?

\section{CHALLENGE}

Make a difference, get involved, and expand geoscience appreciation! If geoscience is vital to the betterment, sustainability, and continuity of humankind and society, it is our responsibility as geologists to educate the non-geologists who don't agree or understand why. We invite you to contribute to this discussion by coming up with your own succinct, measurable, and clear reasons on the importance of your specific discipline in how it affects all aspects of society. Unconventional and unusual reasons are encouraged, and "succinct" is key: we ask you to add your thoughts to our challenge by sending a two-sentence e-mail to gsatoday@geosciety.org or, for those so inclined, posting your answer in a single Twitter or Instagram post. Be sure to tag@geosociety and \#geotomorrow so that your responses may be collected. Responses will be made available for our geoscience community to use, adapt, and advocate with as we continue into the future. As the voice of the Geological Society of America, you are responsible to initiate a surge in geoscience appreciation and understanding. We know what GSA Today is-what is GSA Tomorrow?

\section{REFERENCES CITED}

Fei, H., Yamazaki, D., Sakurai, M., Miyajima, N., Ohfuji, H., Katsura, T., and Yamamoto, T., 2017, A nearly water-saturated mantle transition zone inferred from mineral viscosity: Science Advances, v. 3, p. 1-7, https://doi.org/10.1126/ sciadv.1603024.

Gohau, G., 1991, A History of Geology: New Brunswick, New Jersey, Rutgers University Press, $284 \mathrm{p}$.

Häggquist, E., and Söderholm, P., 2015, The economic value of geological information: Synthesis and directions for future research: Resources Policy, v. 43, p. 91-100, https://doi.org/10.1016/j.resourpol.2014.11.001.

Pearson, D.G., Brenker, F.E., Nestola, F., McNeill, J., Nasdala, L., Hutchison, M.T., Matveev, S., Mather, K., Silversmit, G., Schmitz, S., Vekemans, B., and Vincze, L., 2014, Hydrous mantle transition zone indicated by ringwoodite included within diamond: Nature, v. 507, p. 221-224, https://doi.org/10.1038/nature13080.

Rose, E.P.F., and Clatworthy, J.C., 2008, Fred Shotton: A 'hero' of military applications of geology during World War II: Quarterly Journal of Engineering Geology and Hydrogeology, v. 41, p. 171-188, https://doi.org/10.1144/ 1470-9236/07-034

Woodward, H.B., 1911, History of Geology: New York, G.P. Putnam's Sons, The Knickerbocker Press, 172 p.

Manuscript ReCeived 24 May 2018 REVISED MANUSCRIPT RECEIVED 30 SePt. 2018 MANusCRipt ACCEPTED 8 OCT. 2018 